\title{
The Role of Quality Assurance and the Values of Higher Education
}

\author{
Judith S. Eaton
}

Quality assurance, the internal and external examination of the effectiveness and performance of colleges and universities, has always played a crucial role in sustaining and improving the best of what higher education has done in the past in order to build the future. The "best" includes the core values of academic freedom, institutional autonomy and social responsibility. ${ }^{1}$

Quality assurance has a history of buttressing and, at times, leading our commitment to these fundamental values. In these early decades of the 21 st century, quality assurance has been playing an especially vital role in sustaining core values as higher education takes on the challenges of change and innovation. Quality assurance plays this key role even as we adopt new teaching and learning practices, develop new types of institutions, engage new types of education providers and continue our commitment to expand access and equity in higher education. Add to this the current environment of both the Covid-19 pandemic and the major and painful focus on social change around issues of race and equality, and it is clear that quality assurance efforts are more important than ever.

Quality assurance is essential to sustaining these values in three ways. First, the vision that drives this review of higher education is premised on the worth of these values. Second, quality assurance is a key source of reinforcement and support for

\footnotetext{
${ }^{1}$ For purposes of this article, "academic freedom" refers to the conduct of higher education teaching and learning, research and service without inappropriate influence from external centres of power, whether public or private. "Institutional autonomy" refers to the independence essential to institutions to make academic judgments and to set academic direction, as reflected in institutional policies and priorities in teaching and learning, research and service. "Social responsibility" refers to viewing higher education as including all major organisations and bodies in society and society in general as stakeholders, as well as students and the academic community.
}

\section{J. S. Eaton (ه)}

Council for Higher Education Accreditation, Washington, DC, USA

e-mail: eaton@chea.org 
these values in thousands of colleges and universities around the world as well as emerging new providers. Third, quality assurance can and should be a voice to students and society about these values and how the values are essential to quality higher education.

\section{A Vision of Quality Based on These Values}

Academic freedom, institutional autonomy and social responsibility are built into the fabric of what quality assurance does and its vision of quality. Leaders in quality assurance are clear and emphatic. We cannot have quality education without academic freedom. We cannot have quality universities without institutional autonomy. We cannot sustain the quality of our value to students and society without full awareness and commitment to social responsibility. We have built both internal and external quality review on this edifice of values.

Academic freedom, especially in the current environment of trending populism and authoritarianism as well as the pressures of the Covid-19 pandemic, is particularly threatened as a core value of both higher education and quality assurance. Yet, quality assurance bodies around the world have stood firm in their contention that it is not feasible to sustain a quality higher education institution in which academic freedom is absent. Quality assurance, in its role as a validator of the importance of higher education institutions, is central to affirming the urgency of assuring a university environment that is grounded in freedom of inquiry and freedom of intellectual engagement, the hallmarks of academic freedom. Quality assurance is there to affirm that universities sustain an environment of free expression, have the resources needed to bring together academics to exercise this freedom and to assure a campus climate that encourages this freedom.

Similarly, to speak of a "quality higher education institution" without autonomy is a contradiction. Quality assurance itself provides both an incentive and leadership for maintaining and assuring this autonomy. It is there to affirm that the conditions for such autonomy prevail, both that governance arrangements are grounded in autonomy and that universities fully exercise the needed academic leadership that is the central justification for this autonomy.

Quality assurance also provides evidence that universities can responsibly sustain this autonomy over time. Sustained autonomy is indispensable in assuring that commitment to this academic leadership and direction is embedded in the life of an institution. As the current pandemic has clearly demonstrated, institutional autonomy, combined with academic freedom, created the environment in which higher education sustained much-needed leadership in thought and action, as researchers, scientists and other intellectuals responded quickly and effectively to provide direction, essential data and information as well as the creative thinking fundamental to addressing the current crisis.

Social responsibility as a value has been identified as particularly important for universities during the last several years, in many ways a restatement and expansion of 
the "community service" mission of higher education which is common throughout the world. It accompanies teaching and learning as well as research. Quality assurance is grounding more and more of its work in consideration of social responsibility by focusing attention especially on issues of access, equity, diversity, inclusion and inequality. Universities are increasingly examined for the extent of this commitment and success in carrying out this vital work.

\section{Quality Assurance Is a Key Source of Reinforcement and Support for These Values}

Those institutions that are able to sustain robust commitment to these values benefit from the additional impetus provided by quality assurance. Universities that are perhaps struggling to fully realise these values gain from the very public support and encouragement that emerges from quality review. Faculty, academic administrators, students and employers are all engaged in quality assurance and its key processes of self-study, peer review and institutional evaluation. Quality assurance standards, policies and practices provide a framework and direction for these values. This framework and these various actors help institutions to build investment in these values and view them as part of what is considered quality throughout higher education.

Quality assurance has expanded quietly but dramatically during the past 25 years, moving from a presence in perhaps an initial third of the countries in the world to the current environment in which quality assurance bodies operate in almost every country. A key characteristic in the expansion of quality assurance has been the concomitant expansion of these values. Country after country has been forceful and vocal in its commitment to academic freedom, institutional autonomy and social responsibility. Key multi-national organisations such a UNESCO, OECD and the World Bank that play leadership roles in higher education worldwide have been invaluable here in their clear emphasis on these values as indispensable for higher education. It is hard to conceive, in today's world, that any major effort to establish or reimagine higher quality assurance would exclude these values.

As higher education is undergoing the challenge of significant change and major innovation, quality assurance is challenged as well. Given the range of changes to what higher education is, how it operates and the students it serves, how is quality maintained and, with it, the core values? We are witnessing a major expansion of higher education providers, going beyond traditional institutions and degrees to online education offered not only by higher education but also civil society and the business world. We are starting to talk less about "institutions" or "universities" and more about "providers." The providers are typically online rather than campus-based and certificate- or badge-based rather than primarily focused on degrees. They are open access - challenging the selectivity model that has long accompanied what is considered to be elite education. 
For example, Class Central reported that, in 2019, more than 13 million massive open online courses were available from online providers such as Coursera, FutureLearn and EdX and others, serving more than 100 million students (Shah 2019). These numbers predate the Covid-19 pandemic and the enormous expansion of remote learning. And, increasingly, these providers are offering micro-credentials and even degrees and are establishing partnerships with traditional institutions.

We have witnessed the emergence of new types of institutions such as Minerva Schools (n.d.) with interdisciplinary programmes, interactive learning platforms and a powerful set of international experiences. New networks are emerging as well, such as the European Universities Initiative (n.d.), a conglomerate of European universities enabling students to combine studies from a number of participating institutions across borders to obtain a degree. Multiple teaching and learning platforms are now available, changing the nature of the engagement of students and faculty through establishing effective means of electronic communication for the classroom and, increasingly, for counselling and advising and for extracurricular activities.

All of this means that, first, quality review needs to change to examine quality in these new settings and, second, that creative thought needs to be given to sustaining academic freedom, autonomy and social responsibility in providers offering education in these newer and innovative ways. We need the core values to assure the effectiveness and value of innovative higher education just as we need these values in the traditional realm.

\section{Quality Assurance Can and Should Be a Voice to Students and Society About These Values and How They Are Essential to Quality Higher Education}

Quality assurance, working with higher education, also has responsibility for framing and articulating the core values to students, government, to employers and the public. This is part of its social responsibility dimension. This can be done through using quality review to articulate and examine the social responsibility efforts of higher education, calling on colleges, universities and the emerging providers to, for example, take meaningful action in such areas as access, equity, diversity and inequality. It can be done by demonstrating that academic freedom and autonomy are part of the foundation on which social responsibility is based. In many ways, "social responsibility" is about the role of both quality assurance and higher education in achieving social justice, whether in a country, region or internationally.

As described in the 2017 publication UNIBILITY: University Meets Social Responsibility - 2015-2017 (Wallace and Resch 2017), social responsibility is about institutions embracing a range of stakeholders, taking responsibility for the multiple ways that institutions affect society as well as considering the wider society itself to be a stakeholder. It is about universities moving beyond campuses. This can mean, for example, work with public bodies, university engagement in public policy and 
policymaking and work with business and industry as well as engagement and impact on cultural, civic and social life. Especially as universities and emerging providers frame and carry out their commitment to social responsibility, the activities serve to inform those outside higher education. Higher education can also model some of these activities.

We are living with a combination of the Covid-19 pandemic, concerns with the growth of populism and authoritarianism and social justice needs that are crying out for attention. Higher education can and needs to play a vital role in addressing the range of issues before our societies and strengthen its social responsibility commitment. Nowhere is this more essential now than in issues of race and inequity.

Academic freedom, institutional autonomy and social responsibility are all values essential to higher education, students and society. Quality assurance is keenly aware of its ongoing responsibility to sustain and strengthen these values, not only to protect quality but also to play a central role in building the future of colleges, universities and, going forward, many other providers.

\section{References}

European University Initiative (n.d.), Retrieved from: https://ec.europa.eu/education/events/ european-universities-initiative_en (8.6.2020)

Minerva Schools (n.d.), Retrieved from: https://www.minerva.kgi.edu/about/ (8.6.2020)

Shah, D. (2019, December 2). By the Numbers: MOOCs in 2019. Class Central. Retrieved from: https://www.classcentral.com/report/mooc-stats-2019/ (8.6.2020).

Wallace, M. \& Resch, K. (Eds.) (2017). UNIBILITY: University Meets Social Responsibility-20152017. UNIBILITY Project. Retrieved from: https://www.fpce.up.pt/ciie/?q=en/content/unibility$\%$ E2\%80\%93-university-meets-social-responsibility-0 (8.6.2020)

Judith S. Eaton is President emeritus of the Council for Higher Education Accreditation (CHEA), the national coordinating body for accreditation and quality assurance in the United States. Prior to her work at CHEA, she served as Chancellor of the Minnesota State Colleges and Universities, as President of the Council for Aid to Education, the Community College of Philadelphia and the Community College of Southern Nevada and as vice president of the American Council on Education. She has held teaching positions at Columbia University, the University of Michigan and Wayne State University. 
Open Access This chapter is licensed under the terms of the Creative Commons Attribution 4.0 International License (http://creativecommons.org/licenses/by/4.0/), which permits use, sharing, adaptation, distribution and reproduction in any medium or format, as long as you give appropriate credit to the original author(s) and the source, provide a link to the Creative Commons license and indicate if changes were made.

The images or other third party material in this chapter are included in the chapter's Creative Commons license, unless indicated otherwise in a credit line to the material. If material is not included in the chapter's Creative Commons license and your intended use is not permitted by statutory regulation or exceeds the permitted use, you will need to obtain permission directly from the copyright holder. 